\title{
(Un)markedness of trills: the case of Slavic r-palatalisation*
}

\author{
Marzena Żygis \\ Zentrum für Allgemeine Sprachwissenschaft, Berlin
}

This paper evaluates trills $[\mathrm{r}]$ and their palatalized counterparts $\left[\mathrm{r}^{\mathrm{j}}\right]$ from the point of view of markedness. It is argued that [r]s are unmarked sounds in comparison to $\left[\mathrm{r}^{\mathrm{j}}\right] \mathrm{s}$ which follows from the examination of the following parameters: (a) frequency of occurrence, (b) articulatory and aerodynamic characteristics, (c) perceptual features, (d) emergence in the process of language acquisition, (e) stability from a diachronic point of view, (f) phonotactic distribution, and (g) implications.

Several markedness aspects of $[\mathrm{r}] \mathrm{s}$ and $\left[\mathrm{r}^{\mathrm{j}}\right]$ are analyzed on the basis of Slavic languages which offer excellent material for the evaluation of trills. Their phonetic characteristics incorporated into phonetically grounded constraints are employed for a phonological OT-analysis of r-palatalization in two selected languages: Polish and Czech.

\section{Introduction}

It has often been observed that trills are marked sounds in comparison to other natural classes, e.g. stops or fricatives, which has been especially attributed to the articulatory complexity of these sounds (see e.g. Šimáčková 2003). Similarly, the articulatory complexity has appeared essential for the claim that palatalized trills are marked with respect to other palatalized coronals, e.g., [ $\left.\mathrm{t}^{\mathrm{j}}\right]$, cf. Hall (2000).

In this paper the focus is placed on the markedness relation between trills and their palatalized counterparts. It will be shown that plain trills are unmarked with respect to their palatalized counterparts. The conclusion is drawn from an evaluation of $[r] s$ and $\left[\mathrm{r}^{j}\right] \mathrm{s}$ against several aspects of markedness such as (a) frequency of occurrence, (b) articulatory and aerodynamic characteristics, (c) perceptual features, (d) production in the process of language acquisition, (e)

\footnotetext{
* I would like to thank Susanne Fuchs and Silke Hamann for their comments on this paper.
} 
stability from a diachronic point of view, (f) phonotactic distribution and (g) implications.

A direct contribution of the present analysis to a markedness concept is the involvement of aerodynamic, acoustic and perceptual evidence, mostly neglected in the literature.

Several aspects of $[\mathrm{r}]$ and $\left[\mathrm{r}^{\mathrm{j}}\right]$ will be examined on the basis of Slavic languages which provide excellent material especially for the examination of palatalized trills which are extremely rare sounds, see 2.3 .

The role of markedness of plain and palatalized trills is furthermore examined in the phonology of Czech and Polish. The process of r-palatalisation is analyzed in both languages in the framework of Optimality Theory (OT) (Prince and Smolensky 1993, McCarthy and Prince 1993). It is shown that universal phonetically grounded constraints ranked differently in Polish and Czech lead to the selection of the optimal candidates in both languages.

This analysis is more economic than the one by rules (see Rubach 1984) since it requires neither an intermediate stage, i.e. an abstract segment $/ \breve{r}^{\prime} /$, nor additional Spell-out rules. Constraints alone make a distinction between the treatment of an underlying /ž/ and an underlying /r/, two potential inputs for palatalisation.

The article is organized as follows. In section 2, I evaluate plain and palatalized trills against various markedness relations and I show that aerodynamic evidence as well as perceptual saliency are important aspects of the concept of markedness. In section 3, I propose an analysis of r-palatalisation in Polish and Czech in terms of constraints. My conclusions are outlined in section 4.

\section{The (un)markedness of trills}

\subsection{Rhotics as a natural class}

Before discussing markedness of trills, let us consider the natural class of rhotics of which trills constitute a part. There is no consensus in the literature on how rhotics can be defined as a natural class. The difficulty is caused among others by the wide range of places of articulations (labial, dental, alveolar, postalveolar and uvular) in connection with different manners of articulation starting from trills via taps, flaps and through to approximants. This is shown in (1) where rhotics are systematized according to their place and manner of articulation. Below, some examples of languages are listed in which the single sounds are attested as phonemes. For the sake of completeness a labial trill (B) is also included which does not however belong to rhotics. 
(1) Rhotics + trills $^{2}$

$\begin{array}{lcccc} & \text { labial } & \text { dental/alveolar } & \begin{array}{c}\text { postalveolar } \\ \text { (retroflex) }\end{array} & \text { uvular } \\ \text { Trill } & \text { B } & \text { r }(\check{\mathrm{r}}) & \underline{\mathrm{r}} & \mathrm{R} \\ \begin{array}{l}\text { Flap/taps } \\ \text { Approximants }\end{array} & \mathrm{C} & \mathrm{r} & \\ \text { Fricative } & & \mathrm{I} & \mathrm{I} & \mathrm{B}\end{array}$

B Kele, Titan (Oceanic branch of Eastern Malayo-Polynesian)

r Polish, Russian, Finnish, Icelandic, Kele, Toda, Titan

$\check{r} \quad$ Czech

r Toda

R German

s Hausa (West Chadic subgroup), Ngizim (Chadic branch, Bade subgroup)

r Hausa, Ngizim

I American English, Edo (Niger-Kordofanian language, Kwa group)

l Hausa

B French

There were some attempts to define rhotics with an acoustic feature. It has been suggested by Ladefoged (1975) and Lindau (1978) that rhotics display a common acoustic feature, i.e. a lowered third formant (F3). This conclusion cannot be maintained because as pointed out by Lindau (1985:165) and Ladefoged and Maddieson (1996:244) there are rhotics that do not display such a characteristic, i.e., Swedish and German uvular r-sounds show a third spectral peak over $2500 \mathrm{~Hz}$ and the Arrente retroflex approximant also has a high third formant. However, as recognized by Lindau (1985) rhotics behave phonologically as a natural class and therefore have been specified by the feature [rhotic]. This view is shared by Hall (1997a:107) who provides several arguments in favor of rhotics functioning as a natural class.

A different view is presented by Wiese (2001: 350) who offers a prosodic definition of r-sounds, according to which rhotics constitute a point on the sonority scale between laterals and vowels. However, Wiese points out that there are languages in which $/ \mathrm{r} / \mathrm{s}$ take a different position than the one predicted by the sonority scale, e.g., Polish / rt/, /rd/, /rv/. According to Wiese, such cases have to be treated separately. The present paper attempts to show that the position of $/ \mathrm{r} /$ in such clusters can be explained by taking into consideration the perceptual properties of $/ \mathrm{r} /$, presented in 2.5 .

2 Maddieson and Ladefoged (1996) also list a lateral flap /I/. 


\subsection{Trills and palatalized trills in light of the markedness concept}

The concept of markedness comprises several aspects that refer to different dimensions of linguistic analysis, cf. Trubetzkoy (1931), Jakobson (1941), Chomsky and Halle (1968), Stampe (1972), Bailey (1973), Vennemann (1983, $1988,1989)$. One of the most important characteristics of a marked segment is that it occurs less frequently than its unmarked counterpart in the inventories of the languages of the world. Further, it is acquired later in the process of language acquisition than an unarked segment. This is often connected with more articulatory effort required for the production of a marked than an unmarked sound. From a diachronic perspective a marked segment is often less stable than its unmarked pendant in a sense that it undergoes various kinds of changes. Furthermore, as far as its phonotactics are concerned, a marked segment is more narrowly distributed than its unmarked counterpart. Finally, the presence of a marked sound in a given language implies the occurrence of its unmarked counterpart.

Apart from the properties mentioned above, the present paper also takes into account aerodynamic, acoustic and perceptual evidence, which, besides articulatory characteristics, is indispensable in accounting for the (un)markedness of certain natural classes as, e.g., trills. These sounds are reported to occur fairly frequently in the languages of the world, cf. 2.3., but they are articulatorily and aerodynamically extremely complex, cf. 2.4. This potential conflict can be resolved only if one takes into consideration perceptual characteristics of trills, cf. 2.5 .

As far as the comparison between plain and palatalized trills is concerned, i.e. the main subject of the present study, the aerodynamic, acoustic and perceptual evidence highlights the markedness of palatalized trills providing a complete characteristic of these sounds.

The perceptual aspect of the linguistic markedness follows from two wellknown underlying principles of linguistic developments proposed by Passy (1891), and presented in (2).

(2) Passy's principles (1891:227)

a. Principle of economy:

'languages tend to get rid of anything that is superfluous'.

b. Principle of emphasis:

'languages tend to stress or exaggerate anything that is necessary'.

Both principles can be understood in articulatory and perceptive terms in the way proposed, e.g., by Boersma (1998) who translates the principle of economy into a speaker-oriented principle, see (3a), and the principle of emphasis into a listener-oriented principle, see (3b). 
(3) Boersma's principles (1998:2)

a. A speaker-oriented principle: minimization of articulatory effort

b. A listener-oriented principle: minimization of perceptual confusion

According to the speaker-oriented principle, the articulatory effort put into the process of production of a sound should be minimal, and according to a listeneroriented principle, the sound should be so distinctive perceptually that it is easily distinguishable from other sounds. ${ }^{3}$

For the markedness concept, it means that a marked sound requires more articulatory effort than an unmarked one. As far as the perceptual aspect is concerned, I assume that a marked sound is perceptually less distinct than its unmarked counterpart; for an overview of possible perceptual approaches see Hamann (2003).

In addition to perceptual characteristics, aerodynamic evidence is taken into consideration which is indispensable in illustrating the complexity of trills as well as the differences between trills and their palatalized counterparts.

In the following, I evaluate plain and palatalized trills with respect to the parameters presented in (4).

(4) (a) frequency of occurrence

(b) articulatory and aerodynamic characteristics

(c) perceptual features

(d) emergence in the process of language acquisition

(e) stability from a diachronic point of view

(f) phonotactic distribution

(g) implications

Taking into consideration the parameters in (4) it is expected that if palatalized trills are marked counterparts of plain ones, they should be, in contrast to plain trills: (a) less frequent in the phonemic inventories of the languages of the world, (b) articulatory and aerodynamically more complex, (c) perceptually less salient, (d) acquired later in the process of language acquisition, (e) less stable in diachronic processes, (f) more narrowly distributed in the phonotactics, (g) they imply the presence of plain trills in phonemic inventories.

3 Perceptual markedness has been neglected in the phonological literature since SPE (1968). Recent phonological development has shown the indispensability of perceptual characteristics in accounting for various phenomena, cf., e.g., Flemming (1995), Padgett (1997), NíChiosáin \& Padgett (2001), Hume \& Johnson (2001).

The perceptual aspects of trills have been mentioned by e.g. Passey (1891), Solé (1998). 
In the next sections it will be shown that there are strong arguments in favor of the marked character of palatalized trills following from the examination of parameters listed above.

\subsection{Frequency of occurrence}

Plain trills occur fairly frequently in the phonemic inventories of the languages of the world. The UCLA Phonological Segment Inventory Database (UPSID) in which phonemic inventories of 451 languages are listed, displays 155 languages having a plain trill in their inventories, i.e., 9 languages with a dental trill, 95 with an alveolar trill, 51 with either a dental or alveolar trill.

Palatalized trills occur extremely rarely in the languages of the world. UPSID includes 5 languages having $\left[\mathrm{r}^{\mathrm{j}}\right]$ as a phoneme: Russian (dental), Lithuanian, Bulgarian (alveolar), Saami, and Nenets (dental or alveolar). The list can be extended by some Slavic languages not included in UPSID such as Upper and Lower Sorbian, Polabian and Ukrainian as well as Muinane, Daur and Toda provided by Hall (2000:8).

Additionally, as observed by Hall (2000:9), palatalized rhotics ${ }^{4}$ are less frequent in phonemic systems than palatalized non-rhotics, as, e.g., palatalized nasals or palatalized obstruents, cf. also Bhat (1978), Hock (1986:134ff) and Walsh-Dickey (1997:129ff.).

In summary, the palatalized trills are extremely rarely found in the phonemic inventories of the languages of the world. At the same time their plain counterparts $[\mathrm{r}] \mathrm{s}$ occur fairly frequently as phonemes.

\subsection{Articulatory and aerodynamic characteristics}

In this section articulation and aerodynamics, as well as their interaction in the production of trills and their palatalized counterparts, is provided.

As far as articulation is concerned, there is a consensus in the literature concerning the main articulator of the coronal trills. It is namely the tongue tip that vibrates, cf. Wierzchowska (1971), Bolla (1981), Ladefoged\&Maddieson (1996), Recasens (1991), Recasens \& Pallarès (1999), Hall (2000), Solè (1998, 1999, 2002a,b).

The situation is less clear when palatalized trills are analyzed. Bolla (1982) shows that in the production of Russian $\left[\mathrm{r}^{\mathrm{j}}\right]$ the tongue tip still remains the main articulator while the predorsum is raised which is a typical gesture for

4 This generalization pertains to palatalized trills as well as other palatalized rhotics such as $\left[c^{\mathrm{j}}, \mathrm{R}^{\mathrm{j}}, \mathrm{u}^{\mathrm{j}}\right]$, see Hall (2000:8). 
palatalized sounds. The x-ray tracings in (5) illustrate the articulation of Russian $[\mathrm{r}]$ and $\left[\mathrm{r}^{\mathrm{j}}\right]$, see Bolla $(1981:$ 76, 77).

a. Russian [r]

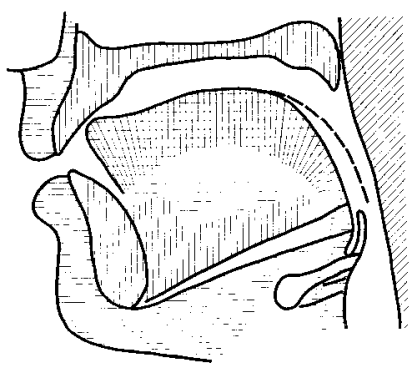

b. Russian $\left[\mathrm{r}^{\mathrm{j}}\right]$

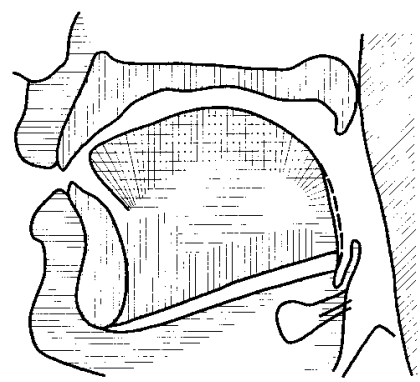

These $x$-ray tracing in $(5 b)$ clearly shows that the tongue tip remains the main articulator in the articulation of Russian $\left[\mathrm{r}^{\mathrm{j}}\right]$. This conclusion has been confirmed by Skalozub (1963) who has shown on the basis of palatograms that Russian [ $\mathrm{r}^{\mathrm{j}}$ ] is articulated with the tongue tip at the dental place of articulation. The articulation of $\left[\mathrm{r}^{\mathrm{j}}\right]$ with the tongue tip has also been postulated for all languages with palatalized rhotics by Hall (2000).

This is in contrast to Polish palatalized trill $\left[\mathrm{r}^{\mathrm{j}}\right]$ which has been shown to be pronounced with the tongue blade, see e.g. Wierzchowska (1971). The x-ray tracings provided in (6) show Polish $[\mathrm{r}]$ in comparison to $\left[\mathrm{r}^{\mathrm{j}}\right]$; see Wierzchowska $(1971: 168,191){ }^{5}$
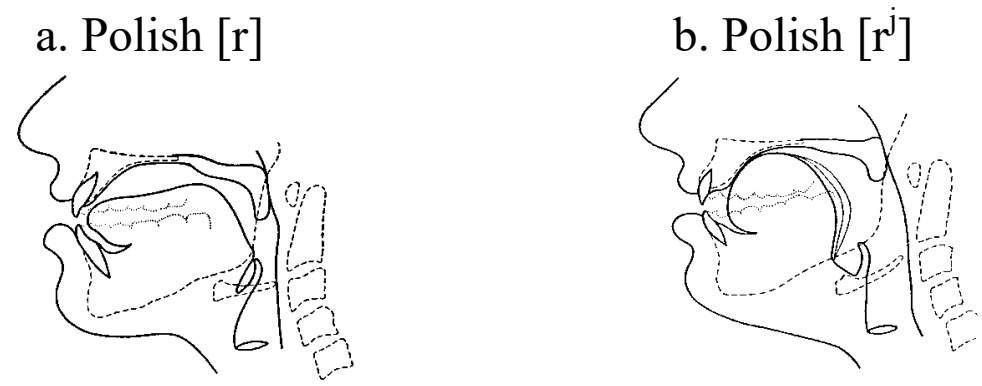

The $\mathrm{x}$-ray tracings provided in (6) show that Polish $\left[\mathrm{r}^{\mathrm{j}}\right]$ is pronounced with the tongue blade whereas $[\mathrm{r}]$ is articulated with the tongue tip. Wierzchowska (1971) is not explicit about this point. In addition, it is also not clear what phase of $\left[\mathrm{r}^{\mathrm{j}}\right]$ articulation is presented by the $\mathrm{x}$-ray tracing in (6).

Apparently there are at least two different manners of articulation of $\left[\mathrm{r}^{\mathrm{j}}\right]$ : with the tongue tip and with the tongue blade. Since in the former case the predorsum is raised, the difference between the two manners are minimal. But a crucial fact for the present paper is that in both cases the articulation requires

5 Note that in Polish $\left[\mathrm{r}^{\mathrm{j}}\right]$ occurs allophonically when [r] is followed by [i] or [j]. Such sequences are limited to words of foreign origin. 
more articulatory effort than in the case of [r]. This is due to the lighter mass and reduced stiffness of the tongue tip which can vibrate more freely than in cases when the tongue tip is accompanied by a raised predorsum or when a tongue blade vibrates, see, e.g., Solè (1998).

Apart from the difficulty of maintaining vibration in $\left[\mathrm{r}^{\mathrm{j}}\right]$ by the main articulator, it has been observed that in this sound two antagonistic articulatory gestures have to be combined, namely, the trill conveys tongue predorsum lowering and backing, whereas a high vocoid requires tongue predorsum raising and fronting, see Recasens \& Pallarès (1999:144). ${ }^{6}$ These two antagonistic gestures tend to be avoided which results in different outputs, see 2.7. Recasens (1991), describing the lingual configuration in the production of [r], also stresses precise (but not antagonistic) requirements on tongue body positioning. He shows for Catalan that there is a clear difference between a production of an apicoalveolar tap $[r]$ and an apicoalveolar trill $[\mathrm{r}]$ in symmetrical VCV sequences in a sense that the latter trill displays lesser $\mathrm{V}$-to-C effects than the tap. Recasens (1999:92) draws the conclusion that the tongue body during the production of $[\mathrm{r}]$ is more constrained than in the production of $[\mathrm{r}]$.

As far as the aerodynamics of trills are concerned, it has been widely observed that the mechanics of trilling resemble the vibration of vocal folds during voicing, cf. Ladefoged and Maddieson (1996). When the mobile tongue tip reaches the hard palate, the air accumulates behind the constriction and the increasing air pressure separates the tongue tip from the palate. Due to the Bernoulli effect the tongue tip is sucked towards the palate and the cycle automatically repeats.

Ladefoged and Maddieson (1996:217) point out that no muscular action controls each single vibration, but 'a sufficiently narrow aperture must be created and an adequate airflow through the aperture must occur.' McGowan (1992) provides a model of a tongue-tip trill production which creates a favourable pressure-flow relation at the tongue tip for sustained vibration. He shows that a trill is the result of interaction between air and the solid tongue tip. What is very important for initiating and sustaining the trill, is the permanent control of the tongue tip, glottal aperture, and the lungs.

Solè $(1998,1999,2000 \mathrm{a}, \mathrm{b})$ who conducted several experiments on the aerodynamics of trills stresses that (voiced) trills require very precise aerodynamic conditions in order to maintain trilling and voicing. On the one hand the oropharyngeal pressure $\left(\mathrm{P}_{0}\right)$ has to be high enough in order to produce and maintain trilling and on the other hand it has to be low enough in order not to impair the transglottal flow required for voicing, see Solè (1998:407). Solè

6 Recasens \& Pallarès (1999) also show that in comparison to [ $r$ ], the trill is more resistant to the effects from [i]. 
estimated the allowable range of aerodynamic variation for trills from aerodynamic data. The results show that $\left(\mathrm{P}_{0}\right)$ may vary between a narrow range of 5.4 to $4 \mathrm{~cm} \mathrm{H}_{2} \mathrm{O}$ in order to sustain voicing and trilling, see Solè (2000b:674). If $\mathrm{P}_{0}$ variations do not fall into this range, the trilling may devoice or cease.

Due to their articulatory and aerodynamic complexity trills are often reported to reduce the number of contacts or lose their trilling and be realized in a different manner. For example, Łobacz (2000) who investigates the production of Polish [r] from an acoustic point of view (with respect to its segmental, spectral and durational properties) reports its very wide variability. She distinguishes four main realization types of $[\mathrm{r}]$ which include single taps, single flaps, multiple taps/flaps, and trills. A similar situation is found in Czech and Serbian. Šimáčková (2001) shows that the Czech alveolar trill is mostly realized as a single contact tap. In some cases the trill appeared as an approximated contact or even a vowel. Out of 150 words containing [r], only 2 were realized with a (two-contact) trill. In Serbian, on the other hand, 55 of the 165 words had a two-to-three contact trill. Solé (2002b) states that Catalan trills usually involve four contacts and less often five or six. In Recasens' \& Pallarès' study (1999:151), the number of cycles for Catalan trills varies between two and five. Bolla (1981:99) observes three to four cycles for the Russian trills. In sum, the number of cycles in the production of trills varies from two to six which also depends on the syllable position, context, speech rate and style.

As far as the aerodynamics of palatalized trills are concerned the oropharyngeal pressure is even higher than in the case of [r]. This is due to the fronting and raising of the tongue dorsum in the case of a high vocoid. Alternatively, Solè (2000b:663) proposes that the higher $\mathrm{P}_{0}$ of trills in the [i] context than in that of the [a] context is to be attributed not only to the high tongue position but also to tongue tension which is higher in the [i] context. In consequence, a higher pressure is needed to cause the tongue-tip to vibrate. If the pressure is higher than the narrow range of possible airflow variation, it is exposed to further modifications, which in consequence might lead to the cessation of voicing or trilling.

In sum, trills articulated with the tongue tip require very precise aerodynamic conditions in order to maintain trilling and voicing. As soon as a trill appears in the context of the following [i], and furthermore becomes palatalized, its articulation requires more articulatory effort due to the raised and fronted predorsum. Such an articulatory setting demands higher pressure in order to trigger vibration which can disturb the conditions required for voicing and trilling. This indicates that palatalised trills are more marked than their plain counterparts. 


\subsection{Acoustic and perceptual features}

As it has been mentioned in the previous section, a trill consists of cycles of vibration produced by the tongue tip. The number of cycles has essential influence on the acoustic and perceptual characteristics of these sounds.

In (7) a spectrogram of a sequence / ra/ excerpted from a Polish word rak 'crab' is presented. The trill $[\mathrm{r}]$ is separated from a following vowel [a] by a bold line.

(7) Spectrogram of Polish [ra]

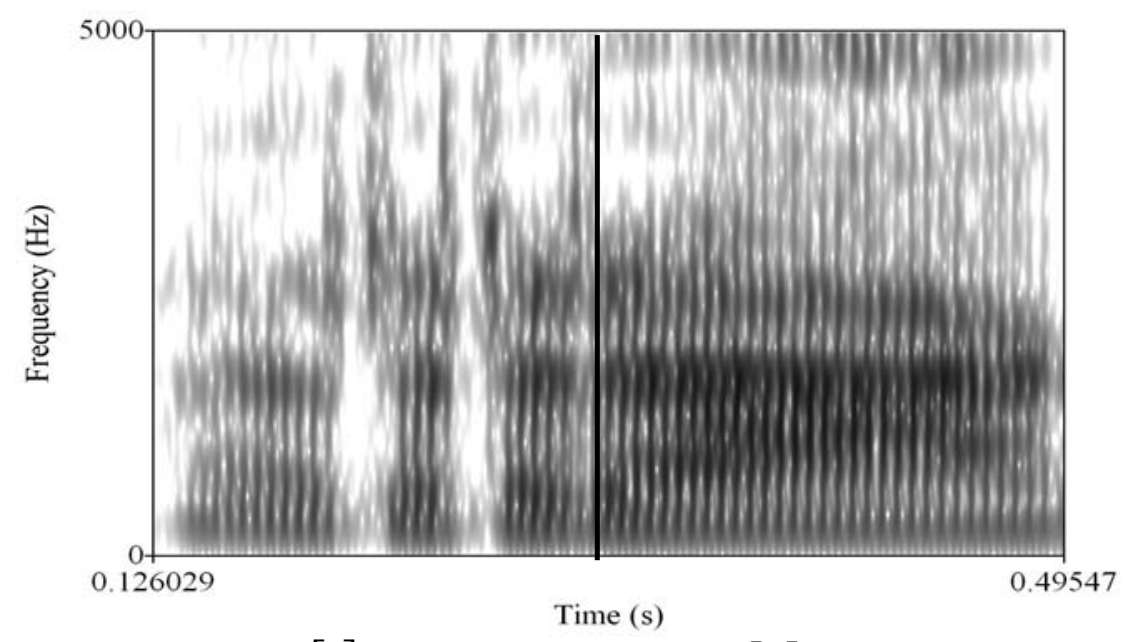

$[\mathrm{r}]$

[a]

The trill in (7) consists of three periods (cycles), each of which is composed by a closed phase and an open phase. In the closed phase the articulators are in contact whereas in the open phase they are slightly apart (Ladefoged \& Maddieson 1996:218). The light areas of $/ \mathrm{r} /$ visible in the spectrogram in (7) correspond to the initial (closed) phase of a cycle because the formant energy is absent or weak, while dark areas show characteristic formant regions indicating concentrations of energy corresponding to the second (open) phase. The duration of cycles and each phase does not always have to be constant. Generally, the first cycle is longer than the following ones. This is due to the oropharyngeal pressure which is higher at the beginning in order to initiate the trilling than to sustain it, see Solè (1998:406).

In the case presented in (7) the first cycle lasts $80 \mathrm{~ms}$, while the second and the third ones are $50 \mathrm{~ms}$ long. As far as the latter cycles are concerned, the closed phase of the second and the third cycle amounts to about $20 \mathrm{~ms}$. The duration of the closed phase of the first cycle is evidently difficult to measure due to the beginning of the signal, i.e. a word-initial position of [r]. Ladefoged 
and Maddieson (1996:218) report on trills where a single cycle also lasts about $50 \mathrm{~ms}$.

How are the acoustic relations mirrored in the perception of trills? If we assume that one cycle of trilling lasts approximately $50 \mathrm{~ms}$ long, then its frequency of vibration is $20 \mathrm{~Hz}$ (20 cycles in a second), cf. also Ladefoged and Maddieson (1996:218). Lindau (1985) who investigated trills of Edo, Degema, Ghotuo, Kalabari, Bumo, Spanish and Swedish produced by a total of 25 speakers reports the mean frequency of vibration to be $25 \mathrm{~Hz}$.

What all the analyses cited above have in common is that the frequency of vibration is at least $20 \mathrm{~Hz}$ which is a crucial characteristic for perception, namely, the frequency of vibration is a conceivable frequency for a human ear, cf. e.g. Zwicker\&Feldtkeller (1967). Importantly, the vibration frequency of 20 $\mathrm{Hz}$ in order to be perceived has to have an amplitude of about $80 \mathrm{~dB}$. My preliminary recordings show that this is exactly the case of Polish trills (from 77,8 to $80 \mathrm{~dB}$ ). Based on this preliminary evidence I assume that the vibration of trilling is perceptually distinguishable. This point obviously requires experimental underpinnings.

As far as the palatalized trills are concerned, their acoustic characteristics considerably differ from that of plain ones. The main difference pertains to the number of cycles. In contrast to plain trills, the palatalized ones display a single cycle of vibration (see Wierzchowska 1971). The cycle is followed by a brief period of frication which overlaps with formants of $/ \mathrm{j} /$.

The spectrogram in (8) shows a sequence of $\left[\mathrm{r}^{\mathrm{j}}\right]$ excerpted from a Polish foreign-word risotto 'risotto.' The bold line separates $\left[\mathrm{r}^{\mathrm{j}}\right]$ from the following [j].

(8) Spectrogram of Polish $\left[\mathrm{r}^{\mathrm{j}}\right]$

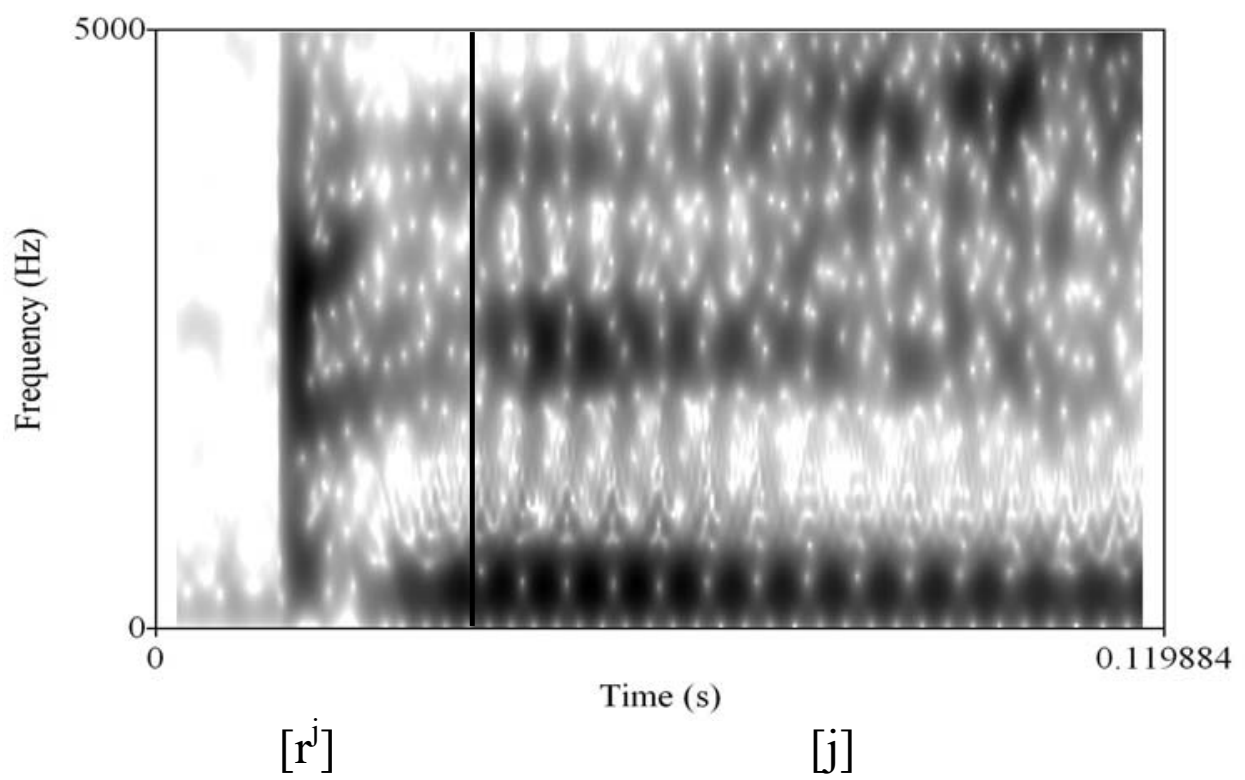


The spectrogram of $\left[\mathrm{r}^{\mathrm{j}}\right]$ in (8) shows that there is a single cycle of the trill, i.e., the trill loses its underlying characteristics, i.e. trilling. Instead the first cycle is followed by a brief period of frication (ca. 15ms) which is to short to be perceivable. ${ }^{7}$ This indicates that the palatalised trill is less salient perceptually than the plain one due to the absence of the trilling and the shortness of frication. These relations change as soon as the frication becomes longer and spectrally more similar to the fricative. In such a case the palatalized trill converts to a fricative trill, as in Czech, or to a fricative sibilant, as in Polish, see 2.7.

\subsection{Emergence of trills in the process of language acquisition}

Starting with undoubted cross-linguistic evidence, trills are acquired late in the process of language acquisition in comparison with other sounds, cf. Vihman (1996). In addition, trills are not present in the babbling stage, cf. Stark (1980).

McGowan (1992) states that Spanish trills (besides sibilants) are the final gestures to be mastered by native speakers. In Polish, as reported by Łobacz (1996) and Zarębina (1980), [r] is required by Polish children at the age of four or even later. This sound is often replaced by [1] or [j]. Similarly, in Russian trills belong amongst the last sounds acquired by children.

As far as the acquisition of palatalized sounds is concerned, they are reported to be acquired even later than plain trills which it typical for secondarily palatalized sounds. This has been shown for Polish by Łobacz (1996) and confirmed for Russian by Gagarina (p.c.).

In sum, in the process of language acquisition trills and palatalized trills are acquired late in comparison to other sounds. In contrast to trills, the palatalized ones are acquired even later than their plain counterparts.

\subsection{Stability in diachronic processes}

Trills are widely reported to undergo various changes especially if they are followed by high vocoids.

Several possible outputs of $/ \mathrm{r} /$ followed by a high vocoid have been

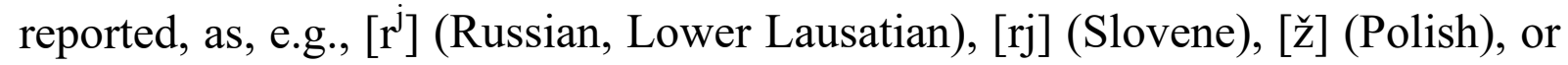
[s] (Jita) $;^{8}$ For example, in Jita, a Bantu language, the stem-final $/ \mathrm{r} /$ changes to [s] before a glide [j] $<y>$ in the process of causative doubling, as shown in (9),

\footnotetext{
7 Sole (2002) states that the audible friction in the range of $50 \mathrm{~ms}$ is required for voiced fricatives (and $30 \mathrm{~ms}$ for voiceless ones).

8 Cf. Banner-Inouye (1995) for other realization of $/ r /$.
} 
cf. Downing (2001), Hyman (1994), Labroussi (1999), Schadeberg (1995), Zoll (1995).

(9) Input

$$
\begin{aligned}
& \text { gur-y-a } \\
& \text { gur-y-ir-a } \\
& \text { gur-y-ir-an-a }
\end{aligned}
$$

\section{Causative Doubling}

$$
\begin{aligned}
& \text { gus-y-a } \\
& \text { gus-i:s-y-a } \\
& \text { gus-i:s-y-a:n-y-a }
\end{aligned}
$$

\author{
'to sell' \\ 'to sell to someone' \\ 'to sell to each other'
}

Slavic languages provide a list of possible developments of [ $\left.\mathrm{r}^{\mathrm{j}}\right]$ which emerged from a Proto-Slavic [r] followed by [j] or front vowels. The process is shown in (10), see Rospond $(1971: 115,116)$. Note that the symbols used in (10) are taken from the original source. I assume that $<\breve{\mathrm{e}}>$ corresponds to the short vowel $[\mathrm{e}]$, the front jer $<_{\mathrm{b}}>$ to a short front vowel which is similar to [1], and the nasal $<_{\mathrm{e}}>$ resembles $[\tilde{\varepsilon}]$.

(10) $\mathrm{r} \rightarrow \mathrm{r}^{\mathrm{j}} \quad /_{-} \mathrm{j}, \mathrm{i}, \mathrm{e}, \mathrm{e}, \mathrm{b}, \mathrm{e}$

In the thirteenth century, the secondary palatalised $\left[\mathrm{r}^{\mathrm{j}}\right]$ became spirantized and converted to a fricative trill [ř ]. In Polish, this sound did not change its place of articulation until the eighteenth century, cf. Stieber (1966:69). Then the fricative secondary articulation became stronger than the primary articulation. Finally, the palatoalveolar fricative [3] was pronounced which changed into a retroflex $[\mathrm{z}]{ }^{9}$

The table in (11) lists the outputs of $\left[\mathrm{r}^{\mathrm{j}}\right]$ in the present Slavic languages,

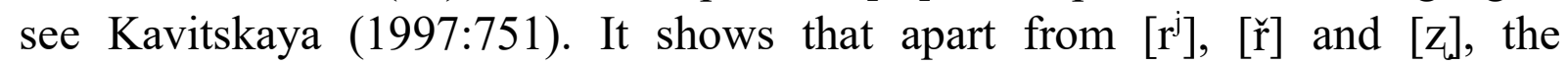
secondary palatalisation was entirely lost, as, e.g., in Belorussian, Croatian, Slovak, Serbian or Macedonian. Finally, the $\left[\mathrm{r}^{\mathrm{j}}\right]$ changed into a sequence of [rj] as in Slovene.

\begin{tabular}{|l|c|}
\hline Language & Output of $/ \mathrm{r}^{\mathrm{j} /}$ \\
\hline Russian & + \\
\hline Belorussian & - \\
\hline Ukrainian & \pm \\
\hline Polish & {$[\mathrm{z}]$} \\
\hline Czech & {$[\check{r}]$} \\
\hline
\end{tabular}

9 The motivation for the change $/ z / \rightarrow$ [z] is discussed in $\dot{Z}$ ygis (2003) in detail. 


\begin{tabular}{|l|c|}
\hline Slovak & - \\
\hline Upper Sorbian & \pm \\
\hline Lower Sorbian & + \\
\hline Slovene & {$[\mathrm{rj}]$} \\
\hline Croatian & - \\
\hline Serbian & - \\
\hline Macedonian & - \\
\hline Bulgarian & \pm \\
\hline
\end{tabular}

$+\quad$ still present in all environments

- $\quad$ former palatalisation entirely lost

\pm former palatalisation partially lost

In sum, trills are reported to be unstable especially in one context, i.e., when they are followed by high vocoids. This context often leads to the emergence of the palatalized trills which in turn are highly apt to undergo changes independently of the context in which they occur.

\subsection{Phonotactic distribution}

According to the markedness concept marked segments have a more narrow distribution than their unmarked counterparts in a given language. Hence, we expect a more limited distribution for palatalized trills than for plain ones in the thirteen (Slavic) languages examined below.

As far as plain trills are concerned, general cross-linguistic evidence shows that trills themselves display a limited distribution in comparison to other sounds because they tend to occur close to the syllable nucleus, cf. Lindau (1985), Ladefoged and Maddieson (1996), Wiese (2001). However, the distribution of palatalized trills is even more restricted. This will be illustrated on the basis of phonotactic restrictions of $/ \mathrm{r} /$ and $/ \mathrm{r}^{\mathrm{j}} /$ occurring in Slavic languages.

The table in Fehler! Verweisquelle konnte nicht gefunden werden.) lists the distribution of plain and palatalized trills according to the syllable position in which they occur. The plain trills are not systematized with respect to the onset coda and a consonant cluster because they are attested in all these positions. 
(12)

\begin{tabular}{|c|c|c|c|c|}
\hline \multirow[t]{2}{*}{\begin{tabular}{|l} 
Language \\
\end{tabular}} & \multirow[t]{2}{*}{ Plain $\mathrm{r}$} & \multicolumn{3}{|c|}{ Palatalized trills } \\
\hline & & Onset & Coda & $\begin{array}{l}\text { Before a con- } \\
\text { sonant }\end{array}$ \\
\hline Czech & $\sqrt{ }$ & - & - & - \\
\hline Polish & $\sqrt{ }$ & - & - & - \\
\hline Slovak & $\sqrt{ }$ & - & - & - \\
\hline Upper Sorbian & $\sqrt{ }$ & $\sqrt{ }$ & - & - \\
\hline Lower Sorbian & $\sqrt{ }$ & $\sqrt{ }$ & $\sqrt{ }$ & $\sqrt{ }$ \\
\hline Bulgarian & $\sqrt{ }$ & $\sqrt{ }$ & - & - \\
\hline Croatian & $\sqrt{ }$ & - & - & - \\
\hline Macedonian & $\sqrt{ }$ & - & - & - \\
\hline Serbian & $\sqrt{ }$ & - & - & - \\
\hline \begin{tabular}{|l|} 
Slovene \\
\end{tabular} & $\sqrt{ }$ & - & - & - \\
\hline Belorussian & $\sqrt{ }$ & - & - & - \\
\hline \begin{tabular}{|l|} 
Russian \\
\end{tabular} & $\sqrt{ }$ & $\sqrt{ }$ & $\sqrt{ }$ & $\sqrt{ }$ \\
\hline Ukrainian & $\sqrt{ }$ & $\sqrt{ }$ & - & - \\
\hline
\end{tabular}

From the table in Fehler! Verweisquelle konnte nicht gefunden werden.), it follows that plain trills are present in every Slavic language in onset, coda and before consonants. Palatalized trills occur only in Bulgarian, Russian, Upper and Lower Sorbian, and Ukrainian. However, their presence is limited to certain positions in a syllable. While in Bulgarian, Upper and Lower Sorbian, Russian, and Ukrainian palatalized trills are found in the onset, their presence in the coda is only attested in Lower Sorbian and Russian. Palatalized trills can also be found in a preconsonantal position, i.e., in consonant clusters. Among Slavic languages, there are only two languages, Russian and Lower Sorbian, in which palatalized trills occur in consonant clusters.

This distribution provides convincing evidence that the palatalized trills are marked in comparison to plain ones in Slavic languages. It also implies markedness positions of palatalized trills: the unmarked place for the realization of a palatalized trill is the syllable onset. A more marked position is a coda and the most marked is a preconsonantal position. The hierarchy of markedness position is presented in (13). ${ }^{10}$ The symbol ' $<$ ' means 'less marked than.'

(13) Positions of markedness of palatalized trills:

onset $<$ coda (word-final) $<$ consonant clusters

10 The hierarchy in (13) also holds true for a diachronic development of palatalisation of labials discussed in Rochon (1999). It has been shown that the secondary palatalisation of labials disappeared in consonant clusters earlier than in word-final positions but is still attested in the onset. 
The hierarchy in (13) is also motivated phonetically. Palatalisation as a secondary articulation is realized in an optimal way when it is followed by a vocalic element, see e.g. Ladefoged and Maddieson (1996). Such an optimal condition is offered by the onset position. A direct perceptual consequence of the presence of a vocalic element is that palatalisation is perceptually much more salient than in a preconsonantal position. Indeed, as the data in (13) indicate the least appropriate position for the realization of palatalisation occurs when a palatalized trill is followed by a consonant, i.e. in a consonant cluster.

A word-final position seems to be more optimal for the realization of the palatalized trills than the preconsonantal position. The distribution of $/ \mathrm{r}^{\mathrm{j}} /$ in Lower Sorbian and Russian shows that the presence of a palatalized trill in a consonant cluster indicates its presence in word-final position but not vice versa. However, from a phonetic point of view it is not exactly clear why this is the case. One of the reasons could be that a secondarily palatalized consonant occurring word-finally might be followed by an initial vocalic element of the next word in connected speech. In the case of consonant clusters no such option is available. Another -more probable reason- could be that in the coda position $[\mathrm{r}]$ contrasts with $\left[\mathrm{r}^{\mathrm{j}}\right]$ and therefore the neutralization of the latter sound is blocked.

Finally, it is worth noting that trills also occur as syllable nuclei. For example, in Czech the trill functions as a syllable nucleus, e.g. $m r k$ 'a wink', mr.kat 'to wink', smrk 'spruce tree', see Šimáčková (2003). Similarily, the syllabic / $r$ / is found in Slovak, Croatian, Serbian and Macedonian (DalewskaGren 2002:88). However, the comparison of trills with their palatalized counterparts within these languages is not possible because $\left[\mathrm{r}^{\mathrm{j}}\right] \mathrm{s}$ are not present in their inventories. I am also not aware of languages having $/ \mathrm{r}^{\mathrm{j}} /$ in a nucleus position.

In sum, the phonotactic distiribution of $[\mathrm{r}]$ and $\left[\mathrm{r}^{\mathrm{j}}\right]$ in the Slavic languages shows that the latter segment is more narrowly distributed in comparison to the former and therefore can be considered as its marked counterpart.

\subsection{Implications}

If palatalized trills are marked sounds, they are expected to imply the presence of the plain trills in the phonemic inventories.

In the languages I examined there are no exceptions concerning this point. Languages having $\left[\mathrm{r}^{\mathrm{j}}\right]$ in their phonemic inventories include also the plain trill [r], cf. languages listed in UPSID as Bulgarian, Nenets, Lithuanian, Russian, Saami as well as Daur (Wu 1996), Muinane (Walton\&Walton 1967), Polabian (Polański 2002), Upper and Lower Sorbian (Schuster-Šewc 1996), Toda (Spajić, Ladefoged \& Bhaskararo 1996) and Ukrainian (Zilyns'kyj 1979). 
Conversely, the plain trill does not imply the presence of the palatalized counterpart which is confirmed by many languages in inventories of which an $/ \mathrm{r} /$ and not $/ \mathrm{r}^{\mathrm{j}}$ / is attested. In UPSID 150 languages of this type are included.

\subsection{Summary}

The evaluation of plain and palatalized trills against several dimensions of linguistic description leads to the conclusion that palatalized trills are marked pendants of plain trills. The $[\mathrm{r}] \mathrm{s}$ are less frequent than $\left[\mathrm{r}^{\mathrm{j}}\right] \mathrm{s}$. The latter are also articulatorily and especially aerodynamically more complex as well as less salient from a perceptual point of view than [r]s. They are also acquired later in the process of language acquisition and are less stable from a diachronic point of view than plain trills. From the point of view of the phonotactics, $\left[\mathrm{r}^{\mathrm{j}}\right] \mathrm{s}$ are more narrowly distributed than $[\mathrm{r}] \mathrm{s}$ and finally their presence implies the presence of $[\mathrm{r}] \mathrm{s}$ in a given language.

A direct theoretic contribution to the concept of markedness is that in order to obtain a complete picture of (un)markedness of trills, aerodynamic, acoustic and perceptual characteristics of the sounds have to be taken into consideration.

The perceptual features of trills also resolve a potential problem arising from the comparison of trills with other natural classes, as e.g. stops or fricatives. It is far from obvious why trills despite their articulatory complexity occur fairly frequently in the languages of the world. This question can be answered only if the perceptual saliency of trills are considered.

\section{A phonological account of r-palatalisation in Polish and Czech}

In the remaining part of the article I will show how the phonetic characteristics of trills and especially their palatalised counterparts are mirrored in the phonology of two Slavic languages, namely, in Polish and Czech. The two languages differ in the output of palatalisation of $/ \mathrm{r} /$ : in Polish $/ \mathrm{r} /$ alternates with [z], while in Czech the output of r-palatalisation is [řr]. What both languages have in common is that palatalisation processes in which $/ \mathrm{r} /$ alternates are not predictable but instead are triggered by a limited number of suffixes, as will be shown below.

\subsection{Data $^{11}$}

In Polish / $\mathrm{r} /$ undergoes Coronal Palatalisation, a rule which converts //s z t d n 1

11 A part of this analysis is presented for Polish in my dissertation (Rochó 2000). 


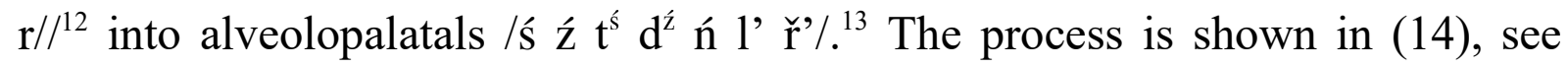
Rubach (1984).

(14) Coronal Palatalisation

$$
\left[\begin{array}{l}
+ \text { anter } \\
+ \text { coronal } \\
\text {-del rel } \\
\alpha \text { obstr }
\end{array}\right] \rightarrow\left[\begin{array}{l}
\text {-back } \\
+ \text { distr } \\
+ \text { high } \\
\text {-anter } \\
\alpha \text { strid }
\end{array}\right] /-\left[\begin{array}{l}
\text {-cons } \\
\text {-back }
\end{array}\right]
$$

Coronal Palatalisation presented in (14) does not generate the surface outputs found in Polish, see (15a), but only intermediate and nonsurface attested steps, see $(15 b)$.
a) $\mathrm{ko} / / \mathrm{r} / / \mathrm{a} \quad \mathrm{ko}[\check{\mathrm{z}}] \mathrm{e}$
'bark' nom.sg./loc.sg.
$\mathrm{ko} / / \mathrm{t} / / \mathrm{o} \quad \mathrm{ko}[\mathrm{l}] \mathrm{e}$
'wheel' nom.sg./loc.sg.
b) $\mathrm{ko} / / \mathrm{r} / / \mathrm{a} \quad \mathrm{ko} / \mathrm{r}^{\prime} / \mathrm{e}$
'bark' nom.sg./loc.sg.
$\mathrm{ko} / / \mathrm{h} / / \mathrm{o} \quad \mathrm{ko} / \mathrm{l}^{\mathrm{j}} / \mathrm{e}$
'wheel' nom.sg./loc.sg.

Since neither $/ \check{\mathrm{r}} /$ nor $/ \mathbf{l}^{\mathrm{j}} /$ are attested outputs of $/ / \mathrm{r} / /$ and $/ / \mathrm{f} / /$ palatalisation in Polish, Rubach (1984) proposes the so-called Liquid Spell-out rule, see (16),

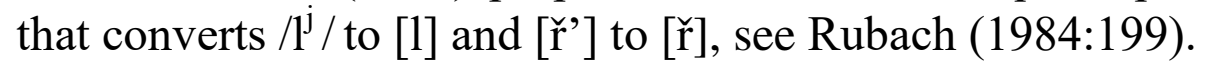

Liquid Spell-out rule

$$
\text { Liquid Spell-out }\left(\begin{array}{l}
- \text { anter } \\
+ \text { sonor } \\
+ \text { cons } \\
- \text { nas } \\
\alpha \text { cont }
\end{array}\right) \rightarrow\left(\begin{array}{l}
- \text { high } \\
-\alpha \text { anter }
\end{array}\right)
$$

The rule in (16) would be sufficient in accounting for the data (see examples

12 Rubach (1984) uses double slashes for marking the underlying representation and single ones for a derivational representation. He also uses traditional Slavic symbols as, e.g., [ž] for the retroflex [z] and ['] for the secondary palatalization. These conventions will be adopted for presenting Rubach's analysis.

13 Another rule accounting for the palatalisation of anterior consonants (the so-called IAnterior Palatalisation) was proposed earlier by Gussmann (1978:86). This rule converts the coronals //s z t d n $\mathrm{r}$ // into their palatalized counterparts /s' z' t' d' n' l' r'/, which subsequently have to undergo various Spell-out rules such as Obstruent Spell-out /s' z' t' $\mathrm{d}^{\prime} / \rightarrow\left[\right.$ ś ź t $\left.^{\varsigma} \mathrm{d}^{\prime}\right]$, Nasal Spell-out $/ \mathrm{n} / \rightarrow[\mathrm{n}]$, r-Spell-out $/ \mathrm{r}^{\prime} / \rightarrow[\mathrm{z}]$, and Lateral Spell-out $/ 1 / \rightarrow[1]$. 
given below). However, [ř $]$ does not occur in the Polish inventory and it not an attested output of r-palatalisation. Therefore in order to get an optimal candidate Rubach (1984) proposes the so-called r-spell-out rule which turns /ř to [r] before a consonant and to [ž] otherwise. This is shown in (17), see Rubach (1984:200).

(17) r-Spell-out rule

$$
\text { r-spell-out }\left(\begin{array}{l}
+ \text { sonor } \\
+ \text { cons } \\
\text {-anter } \\
\text {-high }
\end{array}\right) \rightarrow{ }_{[+ \text {obstr }]}^{[+ \text {anter }] /}-\mathrm{C}
$$

The first part of the rule in (17) accounts for alternations, e.g. gó//r//a-gó[ž]e 'mountain', sg./pl., see also examples in (18a). The second part of this rule has been postulated in order to account for data in which $/ / \mathrm{r} / /$ is realized as $[\mathrm{r}]$ before palatalizing suffixes starting with consonants. The intermediate stage $/ \check{r}^{\prime} /$ undergoes depalatalisation. Examples in (18) show stems with palatalizing suffixes such as $-\mathrm{c}+\mathrm{a}$ [tsa], $-\mathrm{t}+\mathrm{a}$ [wa], $-\mathrm{n}+\mathrm{y}[\mathrm{ni}]$.

$$
\begin{array}{lll}
\mathrm{dwo} / / \mathrm{r} / /+\mathrm{c}+\mathrm{a} & \mathrm{dwo}[\widetilde{\mathrm{rts}}] \mathrm{a} & \text { 'station' nom.sg./gen.sg. } \\
\mathrm{o} / / \mathrm{r} / /+\mathrm{r}+\mathrm{a} & \mathrm{o}[\mathrm{rw}] \mathrm{a} & \text { 'eagle' nom.sg./gen.sg. } \\
\mathrm{o} / / \mathrm{r} / /+\mathrm{n}+\mathrm{y} & \mathrm{o}[\mathrm{rn}] \mathrm{y} & \text { 'to plough'/'arable' adj. nom.sg. }
\end{array}
$$

According to the rules presented in (14), (16), and (17), the underlying $/ \mathrm{r} /$ in (18) undergoes some derivational steps, as shown in (19).

$$
/ / \mathrm{r} / / \rightarrow / \breve{\mathbf{r}}^{\prime} / \rightarrow / \check{\mathrm{r}} / \rightarrow[\mathrm{r}]
$$

It has to be stressed that there are also cases in which [̌̌] occurs on the surface before the palatalizing suffixes shown above. Examples presented in (20) show that /ž/ is present underlyingly.

$$
\begin{aligned}
& \text { nos }+ \text { o+ro//ž//+c+a nosoro[ }\left[\check{z ̆}^{\mathrm{s}}\right] \mathrm{a} \quad \text { 'rhino' gen.sg. } \\
& \text { tę } \left./ / \check{z} / /+\mathrm{c}+\mathrm{a} \text { tę[žžt }{ }^{\mathrm{s}}\right] \mathrm{a} \quad \text { 'tetanus' gen.sg. } \\
& \mathrm{wy} / / \check{z} / /+1+\mathrm{a} \quad \text { wy[žw]a 'pointer' gen.sg. } \\
& \text { orę//̌̌l/l+n+y orę[žn]y 'armed' adj.nom.sg. }
\end{aligned}
$$

The examples in (15), (18) and (20) show why Coronal Palatalisation converts $/ \mathrm{r} /$ into $/ \breve{\mathrm{r}} /$ followed by an additional Spell-out rule, i.e., $/ \mathrm{r} / \rightarrow / \check{\mathbf{r}} / \rightarrow[\mathrm{r}]$. Rubach (1984:72) motivates this step in the following way: 
"If Coronal Palatalisation changed /r/ to [ž] directly, there would be no way of recovering $/ \mathrm{r} /$ in the contexts where it undergoes depalatalisation. Thus, for instance, wierny 'faithful' and podróżny 'journey' (Adj.) would have the same structure after Palatalisation had applied: /ž+In/"

As far as Czech is concerned there are also processes attested in which $/ \mathrm{r} /$ is palatalized. In contrast to Polish, the output of these processes is the fricative trill [ř ]. But similarly to Polish, the palatalisation output is not predictable and it is triggered by a limited number of suffixes. In (21) alternations /r/ - [ř ] in some morphological contexts are shown: formation of adjectives (a), plural formation in masculine animate declension (b), formation of the 1 ps. sg. from infinitives (c), formation of a possessive adjective (d), formation of the locative singular case in masc., fem. and neut. (e), see Scheer (2001:16).
a) $\operatorname{vyd} / \mathrm{r} /+\mathbf{i} \quad \operatorname{vyd}[\check{r}] \mathbf{i}$
'otter' adj.sg.
b) $\operatorname{dob} / \mathbf{r} /+1$ dob[ř $] 1 ́$
'good' 1 ps.pl.masc.
c) $\mathrm{o} / \mathrm{r} /+\mathrm{u} \quad \mathrm{o}[\check{\mathrm{r}}] \mathrm{u}$
'to plough' 1ps.sg.pres
d) $V e \check{r} / r /+$ in $V e \check{r}[\check{r}]$ in
'Věra' adj.sg.
e) papí/r/e papi[̌r $] \mathrm{e}$
'paper' loc.sg.

Another $/ \mathrm{r} /-[\check{\mathrm{r}}]$ alternation context is the vocative case of masculine nouns. In (22) there are examples in which $/ \mathrm{r} /$ in the nominative of masculine nouns alternates with [ř $]$ in the vocative, see Scheer (1998:56). It has to be stressed that this alternation occurs only in cases where the trill is preceded by an obstruent, cf. (22a) and not by vowels, cf. (22b).

\begin{tabular}{|c|c|c|}
\hline Nominative & Vocative & \\
\hline $\mathrm{kmot} / \mathrm{r} /$ & $\operatorname{kmot}[\check{r}] \mathrm{e}$ & 'godfather' \\
\hline svet/r & svet[r̆ $] \mathrm{e}$ & 'pullover' \\
\hline docto/r/ & $\operatorname{docto}[\mathrm{r}] \mathrm{e}$ & 'doctor' \\
\hline
\end{tabular}

\subsection{An Analysis}

Since in Czech and Polish palatalisation of $/ \mathrm{r} /$ is not predictable I propose that there is a palatalizing feature called $[\mathrm{PAL}]^{14}$ that is a property only of those

14 [PAL] is to be considered as a shorthand for a palatalizing feature, cf. also the discussion on the palatalizing feature by Hall (1997a:82ff). 
suffixes that induce palatalisation. ${ }^{15}$ In (23a) palatalizing Polish suffixes are shown with their representation, while in (23b) representation of Czech palatalizing suffixes is displayed.
a) Polish
${ }_{-}^{[\mathrm{PAL}]}$ ist $+\dot{\mathrm{i}}$ adjectival
${ }_{-}^{[\mathrm{PAL}]}$ isk $+_{\mathrm{O}}$ augmentative
${ }_{-}^{[\mathrm{PAL}]} \mathrm{ic}+\mathrm{a}$ feminine
${ }^{[\mathrm{PAL}]}$ in $+\mathrm{a}$ pejorative

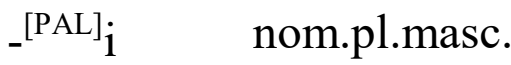
b) Czech

$\begin{array}{ll}{ }_{-}^{[\mathrm{PAL}]} \mathrm{u} & 1 \text { ps. sg. pres. } \\ { }^{[\mathrm{PAL}]}{ }_{1} & \text { nom. pl. masc. animate declension } \\ { }^{[\mathrm{PAL}]} \text { in } & \text { possesive, adj. } \\ { }^{[\mathrm{PAL}]}{ }_{1} \mathrm{i} & \text { nom. adj. } \\ { }_{-}^{[\mathrm{PAL}]} \mathrm{e}^{16} & \text { loc.sg. }\end{array}$

In the following I present an analysis of Polish and Czech data by means of constraints in the framework of Optimality Theory, see McCarthy and Prince (1993), Prince and Smolensky (1993).

In (24) a faithfulness constraint MAX-IO is shown which assures that no segment will be deleted from the underlying representation, see McCarthy and Prince (1995: 264).

\section{MAX-IO}

Every segment in the input has a correspondent in the output.

In order to assure that not only segments but also subsegments such as [PAL] will not be deleted, a constraint called MAX (Subseg) has to be involved in the analysis. The general formulation of MAX (Subseg) is given in (25a) (see Zoll 1996:59) and its specification in (25a).

15 It is important to stress that a floating feature might also project its own root node. For example, in Yowlumne a floating feature either moves to find a suitable docking site in the base or projects its own root node, cf. Zoll (1996:167ff). There are also cases in Polish where a floating feature might emerge as a segment. Traditionally such segments were represented as underlying abstract vowels called jers, which either disappear or are vocalized. Recent studies show that it is possible to represent jers in terms of features, cf. e.g. Gussmann (1992), Szpyra (1992), Zoll (1993), Zoll (1996).

16 I assume that stems which do not undergo palatalisation are additionally specified in the underlying representation, cf. (22). In the present paper I will not analyze such cases. 
(25) a. MAX (Subseg): Every subsegment in the input has a correspondent in the output.

b. MAX [PAL]: Every [PAL] in the input has a correspondent in the output.

The phonetic content of [PAL] will not be specified because its application leads to different outputs in different languages. I assume that there is a range of possible outputs of r-palatalisation ( $\left.\breve{\mathrm{r}}, \breve{\mathrm{r}}^{\mathrm{j}}, \mathrm{r}^{\mathrm{j}}, \underline{\mathrm{r}}^{\mathrm{j}}, \check{\mathrm{z}}, \check{\mathrm{z}}^{\mathrm{j}}\right)$, and MAX [PAL] is satisfied if the featural content of /r/ converts to one of the possible outputs, cf. also the discussion below.

Constraints do not only prohibit deletion of [PAL] but they also have to assure that this subsegment is realized at the appropriate segment, i.e., on the stem-final consonant. Ellison (1995) and Zoll (1996) propose a constraint called No-Intervening, presented in (26), which prohibits intervening material between a category $<\rho>$ (segment, subsegment) and an edge $<\mathrm{E}>$ that can refer to a morphological and prosodic category. The constraint is presented in (26).

(26) No-Intervening ( $\rho$; E; D) There is no material intervening between $\rho$ and an edge $\mathrm{E}$ in domain D, cf. Ellison (1995:2), Zoll (1996:108).

In Polish and Czech, the constraint 'No-Intervening' demands [PAL] to be realized at the right edge of a stem, i.e. the stem-final consonant. Its specific formulation is given in (27).

No-Intervening ([PAL]; Right; Stem)

The interaction of No-I([PAL]; R,S) and MAX [PAL] is given in (28).

\begin{tabular}{|l|c|c|}
\hline $\mathrm{or}^{[\mathrm{PAL}]} \mathrm{u}$ & No-I([PAL];R,S) & $\mathrm{MAX}[\mathrm{PAL}]$ \\
\hline $\mathrm{o}^{[\mathrm{PAL}]} \mathrm{u}$ & & $* !$ \\
\hline $\mathrm{oru}$ & & \\
\hline $\mathrm{o}^{[\mathrm{PAL}]} \mathrm{ru}$ & $* !$ & \\
\hline $\mathrm{o}^{[\mathrm{PAL}]} \breve{\mathrm{r}}^{[\mathrm{PAL}]} \mathrm{u}$ & $* !$ & \\
\hline
\end{tabular}

The first candidate in (28) is selected as the most optimal one since the palatalizing subsegment [PAL] docks on the final-stem consonant. The second candidate violates MAX [PAL] since it deletes the underlying [PAL]. However, it does not incur any violation of No-I([PAL]; R,S) by satisfying it vacuously. Although the third and the fourth candidates satisfy MAX [PAL] by not deleting the palatalizing subsegment [PAL], they are excluded from consideration because they violate No-I([PAL];R,S) by letting [PAL] skip the stem-final 
consonant. Note the final candidate displays two palatalizing subsegments which was possible by insertion of [PAL].

In a similar way the constraints interact in Polish, which is illustrated by an example in (29).

\begin{tabular}{|l|c:c|}
\hline $\mathrm{kor}^{[}{ }^{[\mathrm{PAL}]} \mathrm{e}$ & No-I([PAL];R,S $)$ & $\mathrm{MAX}[\mathrm{PAL}]$ \\
\hline koŕ $^{[\mathrm{PAL}]} \mathrm{e}$ & & \\
\hline kore & & $* !$ \\
\hline $\mathrm{k}^{[\mathrm{PAL}]}$ ore & $* ! *$ & \\
\hline $\mathrm{k}^{[\mathrm{PAL}]}$ or $^{[\mathrm{PAL}]} \mathrm{u}$ & $* ! *$ & \\
\hline
\end{tabular}

The process of palatalisation in Polish is similar to that of Czech in a sense that a candidate who realizes a subsegment [PAL] on its stem-final consonant is selected as optimal. This is illustrated by the first candidate in (29). Although the mechanism is similar there is a crucial difference between Polish and Czech, namely, the r-palatalisation outputs. The tableaus in (28) and (29) show the optimal candidates in terms of their representation but not in terms of their realization ([PAL is still present in the surface representation).

If we assume that the palatalizing feature [PAL] contains the same features in Polish and Czech we will obtain the same palatalisation results, e.g.,

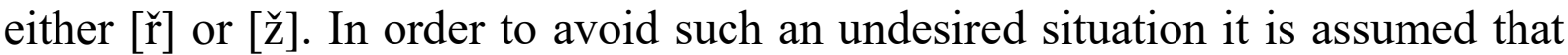
the realization of [PAL] leads to a range of possible outputs of r-palatalization shown in (30). The selection of optimal outputs is regulated by the markedness constraints differently ranked in individual languages, cf. the analysis below. Note the for the sake of convenience I dispense with the voiceless counterparts of these segments. However, there are languages in which voiceless sibilants are output of the palatalisation, cf. examples in Jita shown in (9).

$$
\check{\mathrm{r}}, \check{\mathrm{r}}^{\mathrm{j}}, \mathrm{r}^{\mathrm{j}}, \underline{\mathrm{r}}^{\mathrm{j}}, \check{\mathrm{z}}, \check{\mathrm{z}}^{\mathrm{j}}
$$

All the segments are listed in terms of features in (31) ${ }^{17}$ Segments which are palatalized in terms of secondary articulation, i.e., $\breve{\mathrm{r}}^{\mathrm{j}}, \mathrm{r}^{\mathrm{j}}, \underline{\mathrm{r}}^{\mathrm{j}}, \breve{\mathrm{z}}^{\mathrm{j}}$ are specified as [-back, +high]. Two other segments $\check{r}$ and ž specified as [0 back, 0 high] are neither palatalized nor velarized.

$17[-$ back, + high $]=$ palatalized, $[+$ back $]=$ velarized, $[0$ back, 0 high $]=$ neither palatalized nor velarized. 
(31)

\begin{tabular}{c|c|c|c|c|c|c} 
& $\check{\mathrm{r}}$ & $\check{\mathrm{r}}^{\mathrm{j}}$ & $\underline{\mathrm{r}}^{\mathrm{j}}$ & $\mathrm{r}^{\mathrm{j}}$ & $\check{\mathrm{z}}$ & $\check{\mathrm{z}}^{\mathrm{j}}$ \\
\hline$[$ cor] & + & + & + & + & + & + \\
\hline$[$ ant] & + & + & - & + & - & - \\
\hline$[$ dist] & + & + & - & - & - & - \\
\hline$[$ back] & & - & - & - & & - \\
\hline$[$ high] & & + & + & + & & + \\
\hline$[$ son] & - & - & + & + & - & - \\
\hline [strident] & + & + & - & - & + & + \\
\hline$[$ rhotic] & + & + & + & + & - & -
\end{tabular}

In (32) the segments are formulated as markedness constraints. They are limited to three constraints relevant for the analysis of r-palatalisation in Polish and Czech.

$$
\begin{array}{ll}
*[\check{\mathrm{r}}]: & {[\check{\mathrm{r}}] \text { is avoided. }{ }^{18}} \\
*[\check{\mathrm{Z}}]: & {\left[\check{\mathrm{Z}}^{\breve{j}}\right] \text { is avoided. }} \\
*[\check{\mathrm{Z}}]: & {[\check{\mathrm{Z}}] \text { is avoided. }}
\end{array}
$$

The constraints in (32) express the avoidance of the given sounds due to their articulatory complexity: [̌r] is a laminal trill in which the tongue blade vibrates, whereas $[\check{z}]$ and $\left[\check{z}^{j}\right]$ are retroflex sounds. The palatalisation of retroflex sounds has been argued to be avoided, see Hall (2000), or even impossible, see Hamann (2003).

The interaction of the constraints in (32) together with No-I([PAL];R, S)

\begin{tabular}{|c|c|c|c|c|c|}
\hline $\mathrm{ko} / \mathrm{r} /+{ }^{[\mathrm{PAL}]} \mathrm{e}$ & $*[\check{r}]$ & : * $\left[\begin{array}{l}\mathrm{z} \\
\mathrm{z}\end{array}\right.$ & $\begin{array}{l}\text { No- } \\
\mathrm{I}([\mathrm{PAL}] ; \mathrm{R})\end{array}$ & MAX[PAL] & $*[\check{z}]$ \\
\hline$\overline{\mathrm{ko}[\mathrm{r}] \mathrm{e}}$ & $* !$ & & & & \\
\hline $\mathrm{ko}\left[\check{\mathrm{z}}^{\mathrm{j}}\right] \mathrm{e}$ & & *! & & 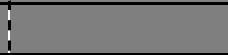 & \\
\hline ko[ž $] \mathrm{e}$ & & & & & * \\
\hline $\mathrm{ko}[\mathrm{r}] \mathrm{e}$ & & & & $* !$ & \\
\hline
\end{tabular}
and MAX [PAL] is illustrated in (33) for Polish.

The candidate $k o[z]$ e is selected as optimal, because the feature [PAL] is realized on the stem-final consonant and it does not violate the high-ranking constraints.

\footnotetext{
18 (a) * [-dist, -back] (*[̌̌’ $])$

(b) * [+dist, +rhotic $](*[\check{r}])$

(c) * [-dist, -ant $](*[\check{z}])$
} 
In Czech the constraint ranking looks differently. In (34) the selection of the candidate dobř́ is shown in (34).

\begin{tabular}{|c|c|c|c|c|c|}
\hline $\mathrm{dob} / \mathrm{r} /+{ }^{[\mathrm{PAL}]} i_{1}^{\prime}$ & $*\left[\check{Z}^{j}\right]$ & $*\left[\begin{array}{c}* \\
z\end{array}\right]$ & \begin{tabular}{|l|} 
No- \\
$\mathrm{I}([\mathrm{PAL}] ; \mathrm{R})$
\end{tabular} & MAX[PAL] & $*[\check{\mathrm{r}}]$ \\
\hline $\operatorname{dob}[\check{r}] 1 ́$ & & 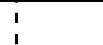 & & 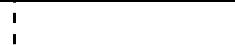 & * \\
\hline $\operatorname{dob}\left[\mathrm{z}^{\prime}\right] \mathrm{i}$ & $* !$ & 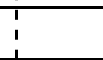 & & 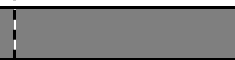 & \\
\hline dob[ž]í & & $! * !$ & & 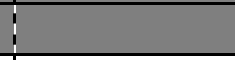 & \\
\hline $\operatorname{dob}[\mathrm{r}] \mathrm{i}$ & & 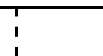 & & $* !$ & \\
\hline
\end{tabular}

The first candidate in (34) is selected as optimal. This is due to the low-ranking markedness constraint prohibiting [ř $]$.

If we take into consideration Polish r-palatalisation in cases when $/ r /$ is followed by consonant-initial suffixes, the ranking proposed thus far for Polish selects a candidate that is unattested in Polish. This is illustrated by the tableau in (35).

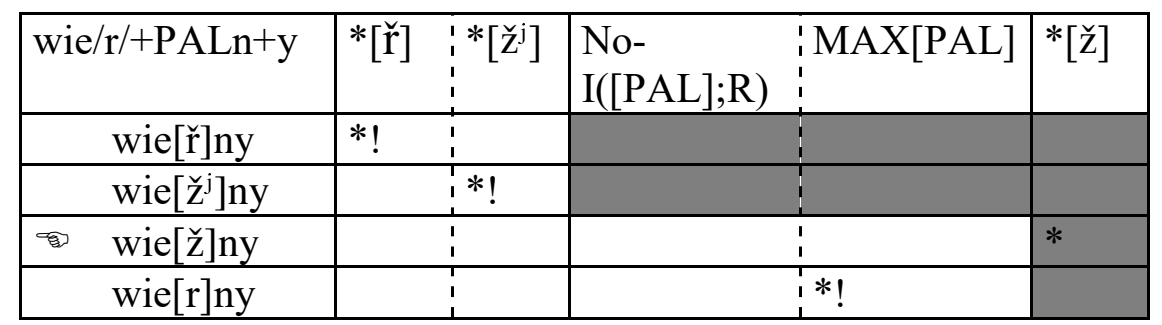

The $/ \mathrm{r} /$ in the underlying representation wie/r/ $+P A L n+y$ undergoes palatalisation and the candidate wie[ž]ny is selected as optimal. However, this candidate proves false since it is not attested in Polish. The attested candidate wie [r]ny is not selected because it violates MAX [PAL] by rejecting palatalisation.

A constraint that is responsible for the selection of the optimal candidate is shown in (36).

(36) Faith $(\mathrm{rC}) \quad / \mathrm{r} /$ is not changed when followed by a consonant.

The constraint Faith ( $\mathrm{rC}$ ) prevents any changes of the feature context of $/ \mathrm{r} /$ if it is followed by another consonant. It does not allowed $/ \mathrm{r} /$ to be palatalized either by a secondary articulation or by changing the place of articulation. A phonetic grounding of this constraint is that a preconsonantal position is the least appropriate position for palatalisation of trills.

In the ranking for Polish Faith $(\mathrm{rC})$ is ranked very high since there is no alternation of $/ \mathrm{r} /$ if it is followed by a consonant. Therefore only the candidate that is faithful to the underlying representation proves as optimal. Consider the tableau in (37). 
(37)

\begin{tabular}{|c|c|c|c|c|c|}
\hline wie/r/+PALn+y & \begin{tabular}{|l} 
Faith \\
$(\mathrm{rC})$
\end{tabular} & 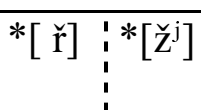 & No-I([PAL];R) & MAX[PAL] & $*[\check{z}]$ \\
\hline wie[ř]ny & $* !$ & $* !$ & & & \\
\hline wie[ž́]ny & $* !$ & $* !$ & & & \\
\hline wie[ž]ny & $* !$ & & & & $*$ \\
\hline wie[r]ny & & & & * & \\
\hline
\end{tabular}

The last question concerns palatalisation of retroflexes in Polish when they are followed by palatalising consonant-initial suffixes. In (38) it is shown that a markedness constraint $*\left[\check{z}^{j}\right]$ prohibiting palatalized retroflexes is responsible for the selection of the optimal candidate.

\begin{tabular}{|c|c|c|c|c|}
\hline podró/ž/+PALn+y & $*\left[\check{Z}^{i}\right]$ & $\begin{array}{l}\text { No- } \\
\text { I([PAL];R) }\end{array}$ & MAX[PAL] & $*[\bar{z}]$ \\
\hline$*$ podró[ž]ny & & & * & \\
\hline podró[ž́j]ny & $* !$ & & I & \\
\hline
\end{tabular}

Alternatively, one could invoke faithfulness constraints that are responsible for the stability of flat retroflexes in Polish. The constraints are shown in (39). ${ }^{19}$

$$
\text { Ident (+back, -anterior, -distributed): Faith ( } \left.\check{\mathrm{s}} \check{\mathrm{z}} \mathrm{t}^{\check{s}} \mathrm{~d}^{\check{L}}\right)
$$

The application of Faith [ž] is shown in (40). The attested candidate podró[ž]ny is selected as optimal.

\begin{tabular}{|c|c|c|c|}
\hline podró/ž/+PALn+y & Faith [ž] & $\begin{array}{l:l}\text { No- } & \text { MAX[PAL] } \\
\text { I([PAL];R) } & \end{array}$ & $*[\check{\mathrm{z}}]$ \\
\hline podró[ž]ny & & 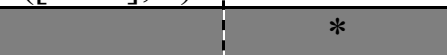 & * \\
\hline podró[ž']ny & *! & & \\
\hline podró[r']ny & $* !$ & & \\
\hline podró[r]ny & *! & & \\
\hline
\end{tabular}

To sum up, it has also been shown that the same universal phonetically grounded constraints ranked differently in Polish and Czech select attested candidates in both languages.

The analysis proposed for Polish also shows that accounting for palatalisation by means of constraints seems to be more economic than by rules since constraints require neither an intermediate stage, i.e. an abstract segment $/ \breve{\mathbf{r}}^{\prime} /$ nor additional Spell-out rules. Constraints alone make a distinction between the treatment of an underlying /ž/ and an underlying /r/, a potential input for palatalisation.

19 Faithfulness constraints that are high-ranking in Polish include: Ident (+high, -anterior, -back,+distributed): Faith (ś $\mathrm{z}^{\mathrm{t}^{s}} \mathrm{~d}^{\prime}$ ń) Ident (+back +anterior, -distributed, +del.release): Faith $\left(\mathrm{t}^{\mathrm{s}} \mathrm{d}^{\mathrm{Z}}\right)$ 


\section{Summary}

The evaluation of trills $[\mathrm{r}]$ and their palatalised counterparts $\left[\mathrm{r}^{\mathrm{j}}\right]$ from the point of view of markedness has shown that despite the articulatory and aerodynamic complexity of $[\mathrm{r}]$, it is an unmarked counterpart of $\left[\mathrm{r}^{\mathrm{j}}\right] \mathrm{s}$. This follows from the evaluation of several aspects of linguistic markedness including aerodynamic, acoustic and perceptual evidence, mostly neglected when discussing (phonological) markedness relations.

The phonetic features of $\left[\mathrm{r}^{\mathrm{j}}\right]$ have been incorporated into universal phonetically grounded constraints employed for a phonological OT-analysis of r-palatalisation in Polish and Czech.

For Polish, it has been shown that in contrast to a derivational account of palatalisation as proposed by Rubach (1984) some abstract unmotivated intermediate stages can be avoided with the help of faithfulness constraints, which due to their highly-ranked status in Polish prohibit the palatalisation of retroflexes and disallow the palatalisation of $/ r /$ if it is followed by another consonant.

The analysis proposed for r-palatalisation in Polish is more economic than by rules since it requires neither an intermediate stage, i.e., an abstract segment $/ \breve{r}^{\prime} /$ nor additional Spell-out rules. Constraints alone make a distinction between the treatment of an underlying / $/ \mathbf{z} /$ and an underlying /r/, two potential inputs for palatalisation.

\section{$5 \quad$ References}

Bailey, C.-J. N. (1973). Variation and Linguistic Theory. Arlington: Center for Applied Linguistics.

Banner-Inouye, S. (1995). Trills, Taps and Stops in Contrast and Variation. PhD thesis. Los Angeles, University of California.

Bhat, D.N.S. (1973). Retroflexion: an areal feature. Working Papers on Language Universals. 27-67.

Boersma, P. (1998). Functional Phonology. Formalizing the interactions between articulatory and perceptual drives. The Hague: Holland Academic Graphics.

Bolla, K. (1981). A Conspectus of Russian Speech Sounds. Budapest: Akademiai Kiado.

Chomsky, N \& M. Halle (1968). The Sound Pattern of English. New York: Harper and Row.

Dalewska-Greń, H (2002). Języki słowiańskie. Warszawa: Wydawnictwo Naukowe PWN.

Delattre, P. (1971). Pharyngeal Features in the consonants of Arabic, German, Spanish, French, and American English. Phonetica 23: 129-155.

Downing, L. J. (2001). Jita Causative Doubling and Paradigm Uniformity. Paper presented at Conference on Paradigm Uniformity, ZAS, March 9-10.

Ellison, T. M. (1995). Phonological Derivation in Optimality Theory. Ms, University of Edinburgh. 
Flemming, E.S. (1995). Auditory representations in phonology. Ph.D. dissertation, UCLA. [Published (2002). New York: Garland]

Gussmann, E. (1992). Back to front: Non-linear palatalisation and vowels in Polish. In: Fisiak, J. and S. Puppel (eds.) (1992). Phonological Investigations. Amsterdam: Benjamins. 5-66.

Hall, T.A. (1997a). The Phonology of Coronals. Amsterdam: Benjamins.

Hall, T.A. (1997b). The Historical Development of Retroflex Consonants in Indo-Aryan. Lingua 101: 203-221.

Hall, T.A. (2000). Typological generalizations concerning secondary palatalisation. Lingua $110: 1-25$.

Hamann, S. (2003). The Phonetics and Phonology of Retroflexes. Utrecht: LOT.

Hardcastle, W. J. and N. Hewelett (1999). Coarticulation. Theory, Data and Techniques. Cambridge: Cambridge University Press.

Hume, E. \& K. Johnson (eds.) (2001). The Role of Speech Perception Phenomena in Phonology. San Diego, CA: Academic Press.

Hyman, L.M. (1994). Cyclic phonology and morphology in Cibemba. In: Cole, J. \& Ch. Kisseberth (eds) Perspective in Phonology. CSLI, 81-112.

Kavitskaya, D. (1997). Aerodynamic constraints on the production of palatalised trills: the case of Slavic trilled [r]. In: Proceedings of Eurospeech 1997, vol. 4 . 751-754.

Labroussi, C. (1999). Vowel systems and spirantization in S.W. Tanzania. In J.-M. Hombert \& L. M. Hyman (eds). Bantu Historical Linguistics: Theoretical and Empirical Perspectives. CSLI, 335-377.

Ladefoged, P. (1975). A course in phonetics. (1st edition). New York: Harcourt Brace Javanovich.

Ladefoged, P. \& I. Maddieson (1996). The Sounds of the World's Languages. Cambridge, Mass.: Blackwell.

Lindau, M. (1978). Vowel features. Language 54: 541-563.

Lindau, M. (1985). The story of /r/. In: Fromkin, V.A. (ed.) Phonetic Linguistics. Orlando. Academic Press. 157-168.

Łobacz, P. (1996). Polska fonologia dziecięca. Warszawa: Energeia.

Łobacz, P. (2000). The Polish Rhotic. A Preliminary Study in Acoustic Variability and Invariance. Speech and Language Technology 4: 85-101.

Maddieson, I. (1984). Patterns of Sounds. Cambridge: Cambridge University Press.

McCarthy, J. J. \& A. S. Prince (1993a). Prosodic Morphology I. Constraint Interaction and Satisfaction. Ms. University of Massachusetts and Rutgers University.

McCarthy, J. J \& A. S. Prince (1995). Faithfulness and Reduplicative Identity. In: J. N. Beckman, L. W. Dickey \& S. Urbanczyk (eds.). University of Massachusetts Occasional Papers 18: 249-372.

McGowan, R.S. (1992). Tongue-tip trills and vocal-tract wall compliance. Journal of The Acoustic Society of America 91: 2903-2910.

NíChiosáin, M. \& J. Padgett (2001). Markedness, segment realization, and locality. In: Lombardi, Linda (ed.) Segmental Phonology in Optimality Theory. Cambridge: Cambridge University Press.

Padgett, J. (1997). Perceptual distance of contrast: vowel hight and nasality. In Walker, R., Katayama, M. \& D. Karvonen (eds). Phonology at Santa Cruz 5, 63-78. 
Passy, P. (1891). Etude sur les changements phonétiques et leurs caractéres généraux. Paris: Librairie Firmin - Didot.

Polański, K. (2002). Polabian. In: Comrie, B. \& G.G. Corbett (eds.). The Slavonic Languages. London: Routledge. 795-824.

Recasens, D. (1991). On the production characteristics of apicovelar taps and trills. Journal of Phonetics 19: 267-280.

Recasens, D. (1999). Lingual coarticulation. In: Hardcastle, W. and Hewlett, N. (eds.). Coarticulation. Theory, Data and Techniques. Cambridge: Cambridge University Press. 80-104.

Recasens, D. (2001). The Effect of Syllable Position in Consonant Reduction. Ms. Paper presented at Conference on Phonetics-Phonology Interface, Berlin, October 2001.

Recasens, D. \& M. D. Pallarés (1999). A study of $/ \mathrm{f} /$ and $/ \mathrm{r} /$ in the light of "DAC" coarticulation model. Journal of Phonetics, 27: 143-169.

Rochoń, M. (1999). Application of Universal Constraints in Polish: Palatalized Labials. Linguistica Silesiana, 31-59.

Rochoń, M. (2000). Optimality in Complexity: The Case of Polish Consonant Clusters. Berlin: Akademie Verlag.

Rospond, S. (1971). Gramatyka historyczna języka polskiego. Warszawa: PAN.

Romportl, M. (1967). R und das tschechische Konsonantensystem. In: Acta Universitatis Carolinae - Philologica 6. Phonetica Pragensia, 7-27.

Rubach, J. (1984). Cyclic and Lexical Phonology: The Structure of Polish. Dordrecht: Foris.

Schadeberg, T. (1995). Spirantization and the 7-to-5 vowel merger in Bantu. In: Dominicy, M. \& D. Demolin (eds). Sound Change. Amsterdam: John Benjamins. 73-84.

Scheer, T. (1998). A unified model of Proper Government. The Linguistic Review, 15: 41-67.

Scheer, T. (2001). Čestina ve Waršawě. Instytut Anglistyki Uniwersytet Warszawski.Ms.

Šimáčková, S. (2001). Trilled $\mathrm{r}$ in Czech and Serbian. Ms. Palacky University Olomouc.

Šimáčková, S. (2003). Variability in the realization of Czech trilled r. In: Kosta, P., Blaszczak, J., Frasek, J., Geist L. \& M. Zygis (eds.). Investigations into Formal Slavic Linguistics. Berlin: Peter Lang Verlag. 119-135.

Skalozub, L.G. (1963). Palatogrammy i Rentgenogrammy Soglasnych Fonem Russkogo Literaturnogo Jazyka. Kiev: Izdatelstvo Kievskogo Univesiteta.

Solé, M. (1998). Phonological Universals: Trilling, Voicing, and Frication. In: Proceedings of the Twenty-Fourth Annual Meeting of the Berkeley Linguistics Society, 403-416.

Solé, M. (1999). Production requirements of apical trills and assimilatory behavior. In: Ohala, J. Y Hasegawa, M. Ohala, D. Granville \& A. C. Bailey (eds.)

Solé, M. (2002a). Assimilatory processes and aerodynamic factors. In: Gussenhoven, C. \& N. Werner (eds). Papers in Laboratory Phonology: Berlin: de Gruyter. 351-386.

Solé, M. (2002b). Aerodynamic characteristics of trills and phonological patterning. Journal of Phonetics 30, 655-688.

Schuster-Šewc, H. (1996) Grammar of the Upper Sorbian Language. München: Lincom Europa.

Spajić, S., Ladefoged, P. \& P. Bhaskararo (1996). The trills of Toda. JIPA 26: 1-21.

Stark, R.A. (1980). Stages of speech development in the first year of life. In: Yenikomshian, G. , Kavanagh, J.F. \& C.A. Ferguson (eds.) Child Phonology 1: Production. New York: Academic Press. 
Stampe, D. (1972). How I Spent my Summer Vacation. Ph.D dissertation, Ohio State University.

Stieber (1966). Historyczna i wspolczesna fonologia jezyka polskiego. Warszawa: PAN.

Szpyra, J. (1992). Ghost Segments in Nonlinear Phonology: Polish Yers. Language, 68 (2): 277-312.

Trubetzkoy, N. S. (1931). Die phonologischen Systeme. Travaux du Cercle Linguistique de Prague, 4: 96-116.

Van de Velde, H. \& van Hout, R. (eds.) (2001). 'r-atics. Sociolinguistic, phonetic and phonological characteristcs of $/ r /$. Bruxelles: Etudes and travaux.

Vennemann, T. (1983). Causality in language change: Theories of linguistic preference as a basis for linguistic explanations. Folia Linguistica Historica, 6: 5-26.

Vennemann, T. (1988). Preference Laws for Syllable Structure and the Explanation of Sound Change. With special Reference to German, Germanic, Italian, and Latin. Berlin: de Gruyter.

Vennemann, T. (1989). Language change as language improvement. In: Orioles, V. (ed.). Modelli esplicativi della diacronica linguistica. Pisa: Gardini, 11-35.

Vihman, M.M. (1996). Phonological development. Cambridge: Blackwell.

Walsh-Dickey, L. (1997). The phonology of liquids. Ph.D. dissertation, University of Massachusetts, Amherst.

Walton, J. \& J. Walton (1967). Phonemes of Muinane. In: Waterhouse, V. (ed.) Phonemic systems of Columbian languages, 37-47.

Wierzchowska, B. (1971). Wymowa polska. Warszawa: Panstwowe Zaklady Wydawnictw Szkolnych.

Wiese, R. (2001). The phonology of /r/. In. Hall, T.A. (eds.) Distinctive Feature Theory. Berlin: Mouton de Gruyter. 335-368.

Wu, C. (1996). Daur. München: Lincom Europa.

Wurzel, W.U. (1994). Grammatisch initiierter Wandel. Bochum: Brockmeyer.

Wurzel, W.U. (1998). On Markedness. In: Theoretical Linguistics, 24: 153-71.

Zarębina, M. (1980). Język polski w rozwoju jednostki. Analiza tekstów dzieci do wieku szkolnego. Rozwój semantyczny języka dziecka. Kraków: Wydawnictwo Naukowe Wyższej Szkoły Pedagogicznej.

Zilyns'kyj, I. (1979). A phonetic transcription of the Ukrainian Language. Cambridge, Mass.: Harvard University Press.

Zoll, Ch. (1993). Ghost segments and Optimality. The Proceedings of the Twelfth West Coast Conference on Formal Linguistics, 183-199.

Zoll, Ch. (1995). Consonant mutation in Bantu. Linguistic Inquiry, 26: 536-545.

Zoll, Ch. (1996). Parsing below the Segment in a Constraint-Based Framework. Ph.D. dissertation, University of California. ROA-143-0996.

Zwicker, E. \& R. Feldtkeller (1967). Das Ohr als Nahrichtenempfänger. Stuttgart.

Żygis, M. (2003). The Role of Perception in Slavic Sibilant Systems. In: Kosta, P., Blaszczak, J., Frasek, J., Geist, L. und M. Żygis (eds.). Investigations into Formal Slavic Linguistics. Berlin: Peter Lang Verlag. 137-154. 